\title{
Environmental Management Accounting Practices and their Diffusion: The Sri Lankan Experience
}

\author{
A D Nuwan Gunarathne and Yasanthi Alahakoon
}

\begin{abstract}
When implementing environmental management strategies it is important to use effective accounting tools to facilitate corporate decision making. In this context, a body of accounting practices, known as Environmental Management Accounting (EMA), has emerged as an interface between management accounting and environmental management. This paper attempts to provide a snapshot of EMA practices in Sri Lanka using the authors' experience in dealing with several industries. It presents the commonly observed EMA tools and techniques used in Sri Lankan organizations while discussing how they have been diffused through adopters and propagators. Despite the rapid diffusion, the authors do not find a comprehensive and systematic adoption of EMA in Sri Lanka. This situation offers opportunities for Sri Lankan organizations to benefit from the proper adoption of EMA in the future.

Keywords: Corporate Sustainability; Diffusion; Eco-efficiency; Environmental Management Accounting (EMA); Environmental Strategies; Sri Lanka; South Asia
\end{abstract}

\section{Introduction}

The changes in today's ecological environment have affected businesses more intensely than at any other time in history. For instance, this is manifested in the fifteen-fold increase in the global cost of natural disasters between the 1950s and the 1990s (Benson \& Clay 2004). Various recent man-made and natural disasters such as the British Petroleum oil spill in the Gulf of Mexico, hurricanes, the Asian tsunami and global warming have led to serious economic, social and environmental consequences (Gunarathne \& Lee 2015). These incidents drew the increased attention, both globally and locally, to the need for

Nuwan Gunarathne is a Senior Lecturer of the Department of Accounting, Faculty of Management Studies and Commerce, University of Sri Jayewardenepura E-mail: nuwan@sjp.ac.lk (Corresponding author)

Yasanthi Alahakoon is a Senior Lecturer of the Department of Business Administration, Faculty of Management Studies and Commerce, University of Sri Jayewardenepura. 


\section{NSBM Journal of Management}

Vol. 2, No. 1, January - June, 2016

sustainable development (Hopwood et al. 2005). Due to the increasingly interconnected nature of the world economy, the impact of these disasters is felt not only in the specific geographic area where they occur but also on a global scale (Forbes 2011). Recently, in a bid to foster sustainability, world leaders responded by adopting the seventeen Sustainable Development Goals (SDGs) in September 2015 and gave high priority to climate change, among other focus areas (United Nations 2016). Alongside these developments, growing public awareness coupled with increasing media attention has forced corporations to address environmental concerns by adopting cleaner and safer environmental practices (Burritt et al. 2002, Soonawalla 2006). While many organizations consider the environment as subject to risks that should be managed, some organizations have used environmental strategies prudently to generate competitive advantage while achieving economic success.

In order to achieve superior environmental and economic performance simultaneously, it is important to identify and use effective (accounting) tools for corporate managers to make 'right' decisions (Schaltegger et al. 2013, Sroufe et al. 2002). The emergence of such tools reshapes the concept of environmental accounting and makes it essential for business success (Delmas \& Toffel 2004, Lee 2009). In adopting environmental strategies/practices, a body of accounting practices referred to as Environmental Management Accounting (EMA) has emerged as an interface between management accounting and environmental management (Bennett et al. 2002). According to a Chartered Institute of Management Accountants (CIMA) survey on management accounting tools, EMA was ranked among the top five of the most widely used tools in management accounting (CIMA 2009).

A large number of studies on EMA now appear in academic journals, covering different issues and perspectives on the subject. While only a few studies are available on developing countries, most of the EMA studies have focused more on developed countries (Herzig et al. 2012, Gunarathne \& Lee, 2015). Addressing this gap in research, Herzig et al. (2012) provide case studies on South-East Asian economies such as Indonesia, the Philippines, Thailand and Vietnam. However, the EMA practices in other emerging economies in South Asia are largely unknown, even though they play an important role in the global economy. This paper, therefore, attempts to provide a snapshot of EMA practice in Sri Lanka based on the authors' recent experience in several industries (such as apparel, hotel, manufacturing, and plantations). The paper covers the various EMA tools and techniques used by Sri Lankan organizations to highlight the situation while discussing the diffusion of these practices by focusing on the adopters and propagators ${ }^{1}$.

\footnotetext{
1 Adopters are the end users of innovations (Meyer, 2004) and propagators are the proponents whose aim is to maximize the pace and spread of the acceptance of innovation (Bjørnenak, 1997).
} 
This paper makes several contributions. Firstly, though environmental issues are global, their profound impact is greatly felt in regions such as South Asia, which is home to twenty percent of the world's population who use only five percent of the world's land (United Nations Environment Programme -UNEP- \& Development Alternatives 2008, South Asia Co-operative Environment Programme -SACEP- 2014). The South Asian region is plagued with many natural disasters such as floods, droughts, landslides, etc. Its population is heavily dependent on agriculture, which is susceptible to climate change. Hence, the understanding of EMA practices in this region has global importance since it can offer valuable learning experiences for the whole world. Secondly, the Sri Lankan economy, after three decades of civil war, is showing an impressive annual growth. Its average annual growth rate has been 6.4 percent for the period from 2003 to 2012. Further, strategies are under way to increase per capita income to USD 4,000 by 2016 from USD 1,000 in 2004 (Central Bank of Sri Lanka-CBSL-2013). These efforts to improve people's living standards have put great pressure on the ecological environment of Sri Lanka. Hence, an improved understanding on how environment is managed by Sri Lankan organizations offers many practical and policy implications for regulators and policy makers alike. Thirdly, Sri Lanka is said to be one of the world's 35 biodiversity hotspots with many threatened and endangered species in existence (Conservation International 2005). As a small island, Sri Lanka falls into the United Nations Framework Convention on Climate Change $\left(\mathrm{UNFCCC}^{2}\right)$ and the Intergovernmental Panel on Climate Change (IPCC)'s $\mathrm{s}^{3}$ category of 'vulnerable'small island nations which are under threat from various climate change impacts (Ministry of Environment and Renewable Energy 2011). Recent human and organizational activities have threatened Sri Lanka's forests and other natural resources. The lack of effective environmental laws, inadequate law enforcement and inconsistent and weak policies have posed many environmental challenges for Sri Lanka. They include, but are not limited to, deforestation; soil erosion; wildlife populations threatened by poaching and urbanization; coastal degradation from mining activities and increased pollution; mismanagement of land; pollution of freshwater resources by industrial waste and sewage runoff; urban and industrial waste disposal; and air pollution in city areas (CIA 2016). Thus, it is important to understand how the countries vulnerable to such climate change deal with the environment in their development process.

2 UNFCC is an international environmental treaty negotiated at the Earth Summit, in 1992, with the objective of stabilizing greenhouse gas concentrations in the atmosphere.

3 IPCC is the leading international body for the assessment of climate change that was established by the United Nations Environment Programme (UNEP) and the World Meteorological Organization (WMO) in 1988. 


\section{NSBM Journal of Management}

Vol. 2, No. 1, January - June, 2016

The remainder of this paper is organized as follows: The next section presents a brief review of literature followed by the research method. It then presents the findings. The last section of the paper gives the conclusions and future directions.

\section{Literature Review}

\section{Overview of $E M A$}

Even though there is no exact definition ofEMA, Bartolomeo et al. (2000), Bennett et al. (2002), Burritt, et al. (2002), Burritt (2004) and the International Federation of Accountants (IFAC) (2005) offer some definitions. Accordingly, EMA can be understood as the identification, collection, analysis and use of physical information on the use, flows and destinies of energy, water and materials (including waste) and monetary information on environment-related costs, earnings and savings. This indicates that EMA provides two types of information for internal decision making: physical information and monetary information (Burritt et al. 2002, IFAC 2005). Accordingly, two types of EMA systems, namely, physical EMA (PEMA) and monetary EMA (MEMA) can be identified. PEMA provides information on an organization's impact on the natural environment and is expressed in physical units such as kilograms, litres, cubic metres, joules, etc. MEMA provides information on the impact of corporate activities on economic systems and is expressed in monetary units. MEMA typically takes place when a financial value is assigned to PEMA information.

However, it can also arise without any relation to a physical measure. For example, costs such as license fees and environmental system maintenance costs are period costs that do not bear a direct relationship to a physical measure (Burritt et al. 2002, Gunarathne et al. 2014). By analyzing various EMA tools and techniques according to three dimensions/attributes, Burritt et al. (2002) suggest a comprehensive framework (see Figure 1). These three dimensions of EMA information are: time frame (whether the time period is past or future), length of time frame (whether the length of the period is short-term or long-term), and routineness (whether the frequency of information gathering/provision is ad-hoc or routine). 
Table 1: Comprehensive framework for EMA

\begin{tabular}{|c|c|c|c|c|c|}
\hline & & \multicolumn{2}{|c|}{ Monetary EMA } & \multicolumn{2}{|c|}{ Physical EMA } \\
\hline & & Short-term & Long-term & Short-term & Long-term \\
\hline \multirow[b]{2}{*}{ Past } & Routine & $\begin{array}{l}\text { Environmental } \\
\text { cost accounting }\end{array}$ & $\begin{array}{l}\text { Environmentally } \\
\text { induced capital } \\
\text { expenditure and } \\
\text { revenues }\end{array}$ & $\begin{array}{l}\text { Material and } \\
\text { energy flow } \\
\text { accounting }\end{array}$ & $\begin{array}{l}\text { Environmental } \\
\text { capital impact } \\
\text { accounting }\end{array}$ \\
\hline & Ad-hoc & $\begin{array}{c}\text { Ex post } \\
\text { environmental } \\
\text { costing decisions }\end{array}$ & $\begin{array}{l}\text { Environmental } \\
\text { life cycle costing }\end{array}$ & $\begin{array}{c}\text { Ex post } \\
\text { assessment } \\
\text { of short term } \\
\text { environmental } \\
\text { impacts }\end{array}$ & $\begin{array}{l}\text { Life cycle } \\
\text { inventories }\end{array}$ \\
\hline & Routine & $\begin{array}{c}\text { Monetary } \\
\text { environmental } \\
\text { budgeting }\end{array}$ & $\begin{array}{c}\text { Environmental } \\
\text { long term } \\
\text { financial planning }\end{array}$ & $\begin{array}{c}\text { Physical } \\
\text { environmental } \\
\text { budgeting }\end{array}$ & $\begin{array}{l}\text { Long term } \\
\text { physical } \\
\text { environmental } \\
\text { planning }\end{array}$ \\
\hline Future & Ad-hoc & $\begin{array}{l}\text { Relevant } \\
\text { environmental } \\
\text { costing }\end{array}$ & $\begin{array}{c}\text { Monetary } \\
\text { environmental } \\
\text { investment } \\
\text { appraisal } \\
\text { Environmental } \\
\text { life cycle } \\
\text { budgeting }\end{array}$ & $\begin{array}{c}\text { Relevant } \\
\text { environmental } \\
\text { impacts }\end{array}$ & $\begin{array}{c}\text { Physical } \\
\text { environmental } \\
\text { investment } \\
\text { appraisal } \\
\text { life cycle analysis }\end{array}$ \\
\hline
\end{tabular}

Source: Burritt et al. (2002)

\section{EMA Techniques/Practices and their Benefits}

As Table 1 shows, EMA encompasses a wide array of accounting tools and techniques used for internal decision making. Hence, it is not merely an environmental management tool but a broad set of principles and approaches that provide information for the successful implementation of environmental strategies (IFAC 2005). EMA includes a wide array of accounting practices such as accounting for energy, material accounting, carbon accounting, environmental capital budgeting, activity-based costing, environmental impact assessment, life cycle analysis, bio-diversity accounting, etc. (Bennett \& James 1997, Environmental Protection Agency - EPA- 1995, IFAC 2005, Jones 1996, Soonawalla 2006). Day by day, new EMA practices are being introduced or existing management accounting practices adopted to fit various environmental management strategies pursued by the organizations (Gunarathne et al. 2014). 


\section{NSBM Journal of Management}

Vol. 2, No. 1, January - June, 2016

Since the range of decisions affected by environmental issues is increasing, EMA is becoming more and more important, not only for environmental management decisions but also for all types of management activities. Though the specific uses and benefits of EMA are numerous, its benefits can be divided into three broad interrelated categories, viz., compliance efficiency, eco-efficiency and strategic positioning (IFAC 2005, Doody 2010). Firstly, EMA facilitates compliance efficiency by ensuring compliance with external environmental regulations and self-imposed environmental policies. For instance, EMA provides the vital information for planning and implementing pollution control or introducing cost effective substitutes for toxic materials (IFAC, 2005). Secondly, EMA supports the simultaneous reduction of costs and environmental impacts via more efficient use of resources to achieve ecoefficiency. Eco-efficiency is a combination of both business case $e^{4}$ (to emphasize the benefits for the shareholders) and business performance (to achieve cost reduction and efficiency) (Williamson et al. 2006). Alternative environmental cost categorization methods in EMA allow organizations to carefully identify different environment costs (refer EPA 1995 and IFAC, 2005 for more details). Thirdly, the use of EMA will strengthen an organization's long-term strategic position. It can be used with the marketing strategy of an organization to improve the green image of the organization, to attract environment-conscious customers, suppliers and investors. This market success motivation enables companies to generate reputational and competitive advantage by providing analytics and reliable statistics to communicate with the markets on the improvements of the organization in relation to environment (Windolph et al. 2014). It should also be noted that these three broad benefits of EMA are not mutually exclusive (IFAC 2005). In essence, EMA, with its assortment of accounting tools and techniques, is a body of practices that supports various environmental strategies of an organization in order to derive its many benefits.

The next section of this paper explains the research method followed in the study.

\section{Method}

The paper is the culmination of mainly the authors' experience with many Sri Lankan organizations both in the private and public (and non-private) sector. Over the past few years, as a part of various research projects, industry collaboration and many other activities, the first author was able to gain a fair understanding of how EMA is practiced in Sri Lanka and how it has developed to the present level of application. The private sector organizations,

\footnotetext{
$\overline{4}$ Business case is the economic rationale for corporate environmental or sustainability management (Salzmann, et al. 2005).
} 
which the authors have interacted with, are from a variety of industry sectors such as apparel, hotels, manufacturing, banking and finance, and plantations while the other sectors include universities, professional accounting bodies (PABs), government institutions and nongovernmental organizations.

In presenting the EMA practices of organizations, the authors use the term 'Sri Lankan enterprises' with a specific meaning. They observed that some noteworthy EMA practices of some multinational Sri Lankan organizations have been largely influenced by the guidelines of their foreign parent companies. Since the authors needed to showcase Sri Lankan practices, only the companies under Sri Lankan ownership and control ('indigenous Sri Lankan enterprises' would be the more suitable term) are included in the paper. Due to this delineation, the practices of many companies that had been pioneers in environmental management in the country have been excluded. Moreover, the authors came across some companies following environmental management initiatives that are purely of a Corporate Social Responsibility (CSR) nature without any direct relationship with their core businesses. Hence, the EMA practices which have no direct impact on business performance have been excluded.

\section{Findings}

The findings of the authors' experiences are organized under two sub-headings: use of EMA in Sri Lanka and diffusion of EMA practices in Sri Lanka. In describing the diffusion of EMA in Sri Lanka, it describes the demand-pull diffusion by focusing on the EMA adopters and supply-push diffusion by focusing on how the propagators have taken initiatives to popularize environmental management/EMA.

\section{Use of EMA in Sri Lanka}

Sri Lankan enterprises, particularly the large private sector companies, follow several common EMA practices in the areas of energy, material, water, carbon, etc. The next section presents these EMA practices.

\section{Accounting for Energy}

In general, almost every Sri Lankan enterprise, irrespective of its size, is concerned about energy management and its associated accounting practices (Gunarathne et al. 2015). Similar to what Wilmshurst and Frost (2001) identified in Australia, a significant number of practices 


\section{NSBM Journal of Management}

Vol. 2, No. 1, January - June, 2016

has been developed in relation to efficient energy use. Hence, accounting for energy is a major EMA tool used by Sri Lankan enterprises. They record the types of energy used, analyze the consumption of energy for different time periods (e.g., during peak and off-peak times), calculate the energy intensity ratio (such as energy consumption per unit/standard minute) and assess the viability of new energy efficient practices. Installation of energyefficient lighting and air conditioning systems, use of alternative types of energy including solar power and bio mass (see Figures 1 and 2), investment in energy efficient tools and equipment are common practices among Sri Lankan enterprises both in the service and manufacturing sectors. It is also becoming a common practice for organizations to carry out an energy audit to identify the energy saving potential. The authors perceive that the high cost of energy is the reason for this heightened interest in energy conservation. Hence, accounting for energy in Sri Lankan enterprises has been mainly driven by internal efficiency motives. This means that it is the eco-efficiency motivation that mainly drives the energy accounting practices among Sri Lankan enterprises.

\section{Figure 1: Use of Alternative Energy Types in the Hotel Sector}

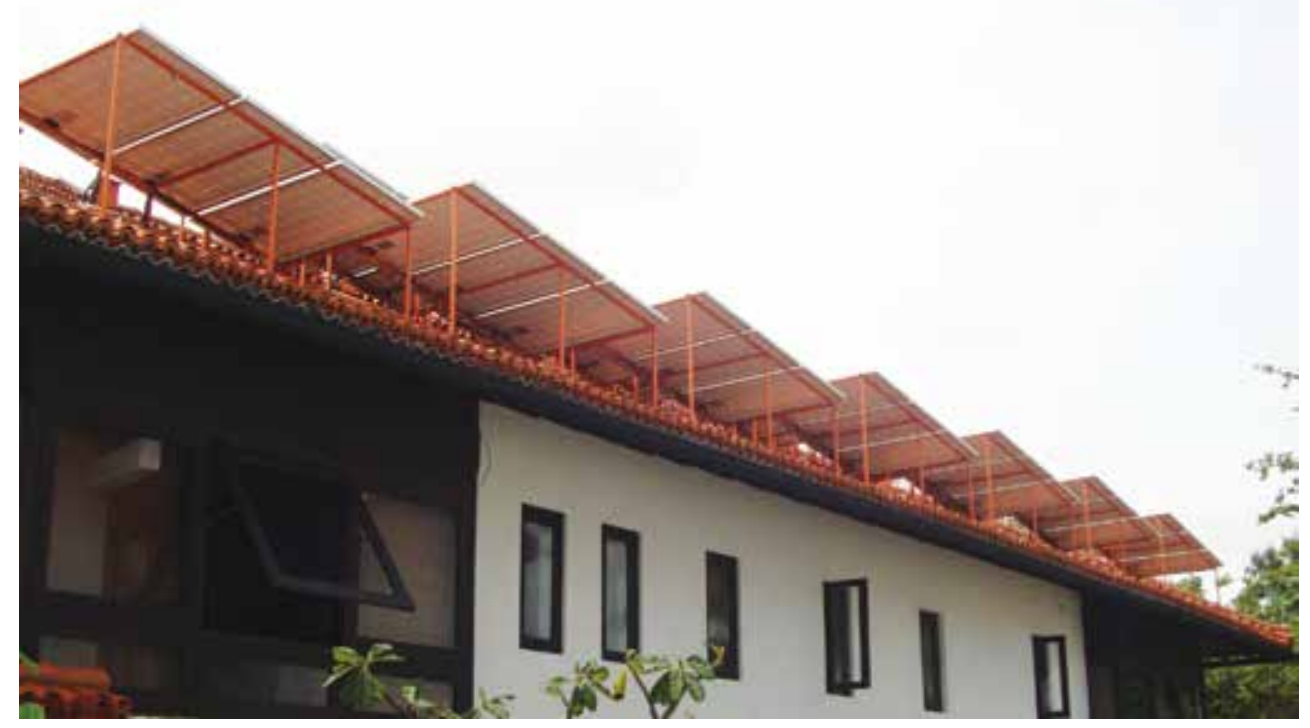

A well-known hotel in Negombo has installed solar panel systems (representing the use of renewable energy) in order to reduce its reliance on electricity obtained from the national grid and to reduce its carbon footprint. Though these investments have a long payback period, the hotel is using its environmentally-friendly sources of energy generation and consumption to derive marketing benefits. 


\section{Figure 2: Physical EMA Applications}

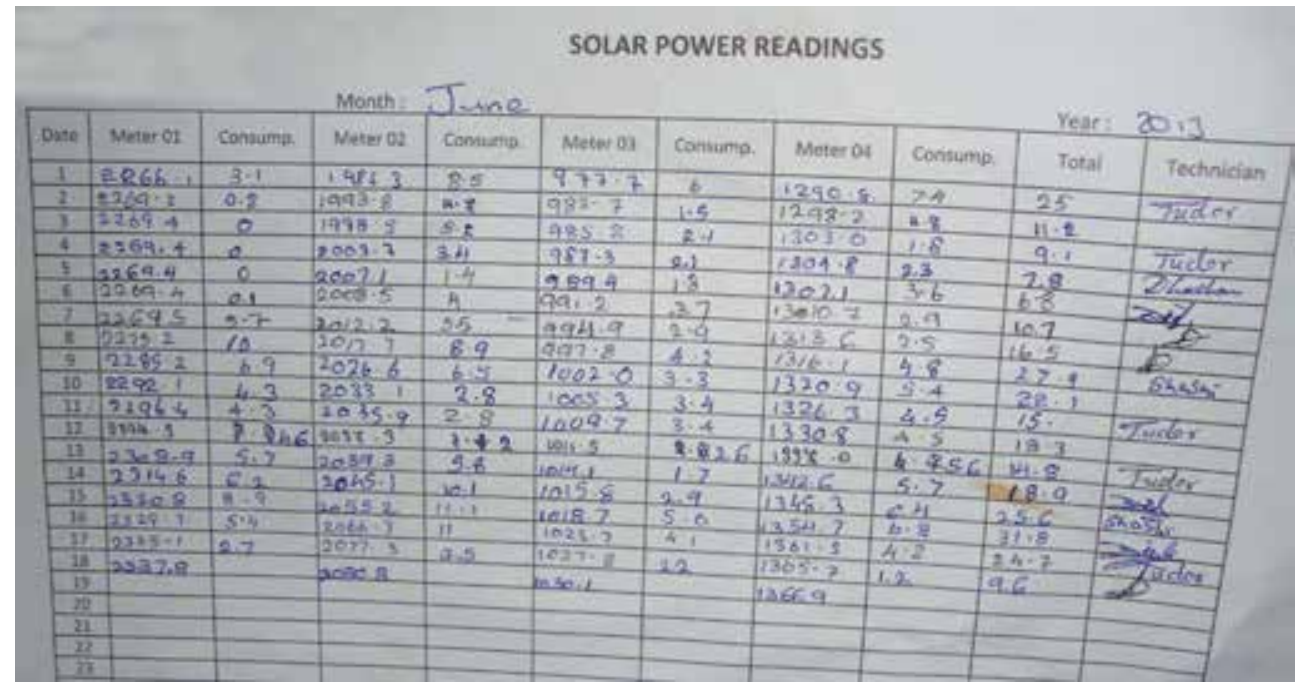

In order to monitor and evaluate investment in solar panels, the hotel keeps daily records of energy generation. They show the electricity cost savings from the installation of the solar panels. These savings in units represent the use of PEMA information. In order to assign a monetary value these units are multiplied by the existing electricity tariff so that the company can use MEMA information.

\section{Accounting for Materials}

In addition to accounting for energy, another important EMA practice followed by Sri Lankan enterprises is accounting for materials particularly in the manufacturing sector (Gunarathne et al. 2015). Depending on the specific industry, the contribution of EMA in relation to the management of material varies. For example, when the raw materials used are costly in industries such as jewelry the authors noticed an intense application of accounting for material, and management commitment and enthusiasm. The authors also noted several accounting for material approaches such as material analysis as per cost centres (or usage centres) by the type of materials, consideration of alternative material, calculation of material cost per unit, analysis of material waste, etc. As Bennett and James (1997) suggest, the collection of data on material flows through an organization is vital for environment-related management accounting. It is the first step in successful waste minimization programmes and may help in accurate product costing. Contrary to the potential benefits suggested by Bennett and James (1997), the authors are not yet convinced of the extent of the use of cost information in pricing decisions by Sri Lankan organizations since product pricing is affected by many other factors. 


\section{NSBM Journal of Management}

Vol. 2, No. 1, January - June, 2016

Although organizations generate information through accounting for materials, it is not used for the application of advanced techniques such as Material Flow Cost Analysis (MFCA). MFCA is a technique with the objective of seeing an organization as a system that channels and transforms flows of materials and information from beginning to end (Strobel \& Redmann 2002, IFAC 2005, United Nations Environment Program -UNEP- and United Nations Industrial Development Organization -UNIDO- 1991). In this way, MFCA systems allow an organization to properly track and control material and waste flows. Despite the potential of MFCA, Sri Lankan enterprises do not use information generated through accounting for material to obtain these benefits. Consequently, most of the waste and waste treatment costs are considered as overheads without linking them to the products which generate them. As Bartolomeo et al. (2000) explain, this may result in these costs being allocated to products which do not, in fact, generate them. Thus, the cleaner products effectively cross-subsidize the other un-clean products. This is where Sri Lankan enterprises can use Activity Based Costing $(\mathrm{ABC})$ in order to trace the overhead costs for the specific activities (and products) which generate them.

For instance, in the apparel sector, manufacturing of certain garments needs special colour dyeing processes. Some of the residues of special colour dyes require careful disposal, resulting in additional costs to the organization. Yet, the authors observed that in many organizations the disposal costs of these dyes are not absorbed by the garment (or customer order) that demanded the use of the special dye. Consequently, the disposal cost is pooled under general overhead costs. Finally, the general overhead costs are charged to all the garments using a standard minute rate. Hence, the cost of the customer order that demanded special colour dyeing processes is cross subsidized by the cleaner garment orders. Similarly, accounting and management for material is mainly driven by the need for eco-efficiency.

\section{Accounting for Water}

Another widespread application of EMA is in the area of water management. Though the cost of water is very low in Sri Lanka, enterprises have started to pay increasing attention to water management and its associated water accounting. Many Sri Lankan enterprises focus on two main approaches to water management: a) behavioural and b) engineering (Gunarathne et al. 2015). Behavioural approaches mainly involve efforts to educate the stakeholders (such as employees, customers, suppliers, etc.) to bring about changes in water use. Engineering approaches involve changes in physical capital directed at preserving water. This may range from water faucets that prevent water waste at the source to water treatment plants. 
For instance, a newspaper printing company, having analyzed water consumption in the toilets, introduced a new urinal system that releases only one litre of water per manual flush. It represents an engineering approach to water management. Owing to the separate metering system in the factory, the management had identified the previous urinals had a continuous water flow with 1,682 cubic meters of water consumption per year.

In order to carry out an investment appraisal for the new urinal system its water consumption estimate was required. The difference between this estimation and the actual water consumption of the existing urinal system is the relevant environmental impact of the investment. This is where both the physical and monetary environmental capital impacts accounting, as shown by Burritt et al. (2002).

Another EMA aspect associated with accounting for water is waste water treatment and accounting. Many organizations have introduced sewerage treatment plants or waste water treatment plants to treat the in-house waste water (and waste materials). For example, in the hotel sector, it was noted that some hoteliers make compost from sewerage, which is either sold or used in their gardens. Adjustment of the water properties (such as the $\mathrm{pH}$ value of the waste water) to be in line with the regulatory requirements before the discharge is a common practice among the Sri Lankan organizations.

In terms of accounting for water, the authors notice the tracking of total water consumption and waste water generation, evaluation of water saving projects, and calculation of water intensity ratio as common practices representing both PEMA and MEMA practices. Due to the absence of cost-saving potential the authors perceive that the waste water treatment is mainly driven by stakeholder pressure such as from consumers (in the hotel sector they are the green-conscious guests) and regulators (see Figure 3). 


\section{NSBM Journal of Management}

Vol. 2, No. 1, January - June, 2016

\section{Figure 3: A Water Treatment Plant of a Soft Drink Manufacturer}

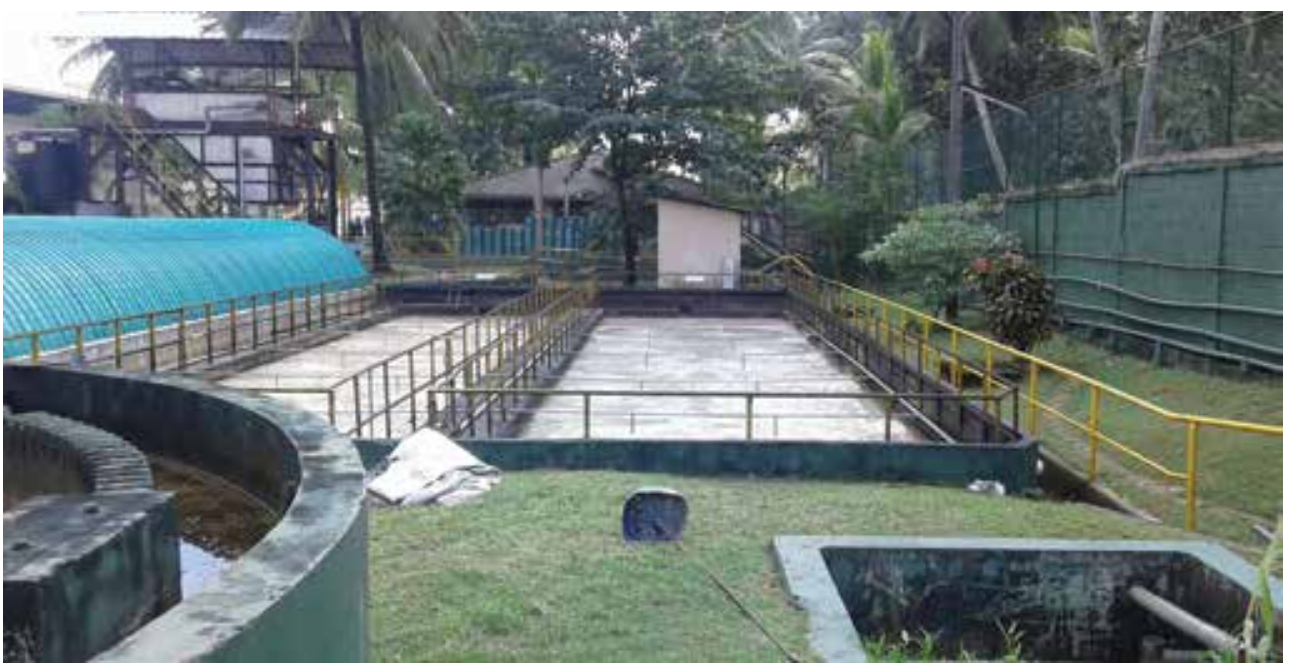

The soft drink manufacturing plant in Sri Lanka has to treat its industrial waste water [i.e., to adjust the water properties such as Chemical Oxygen Demand (COD), Biochemical Oxygen Demand (BOD) and $\mathrm{pH}$ values to the specified tolerance limits] before being discharged. These limits are set by the Central Environmental Authority as per the National Environmental Act, No. 47 of 1980. Thus the waste water treatment practices are largely determined by the regulatory requirements in Sri Lanka.

\section{Accounting for Carbon}

Though less common, another emerging practice is carbon management and carbon footprint accounting. The authors noticed the increasing popularity of this practice in the hotel and garment sectors, in particular. Due to the absence of any regulatory pressure and nonrealization of cost savings, the authors perceive that carbon footprint management is mainly driven by international stakeholder pressures, particularly the customers. One important observation the authors have made here is the reliance on external specialist organizations for carbon footprint management and accounting. This is owing to the technicalities associated with calculating carbon footprint ${ }^{5}$. These consulting firms issue globally accepted Carbon Neutral Certificates or other certifications such as Carbon Conscious Certificates for clients who comply with the requirements. In order to be carbon neutral, these companies generally buy carbon offsets from the carbon markets (see Figure 4).

\footnotetext{
Carbon footprint has to be calculated under three scopes as per Greenhouse Gas Protocol (2004). Scope 1 emissions arise directly from company activities which are owned or controlled by the company and Scope 2 emissions arise from the generation of purchased electricity consumed by the company. Scope 3, which is optional to measure, traces the indirect emissions that result as a consequence of the activities of the company, but from sources not owned or controlled by the company such as employee commuting.
} 


\section{Figure 4: A Carbon Neutral Apparel Factory}

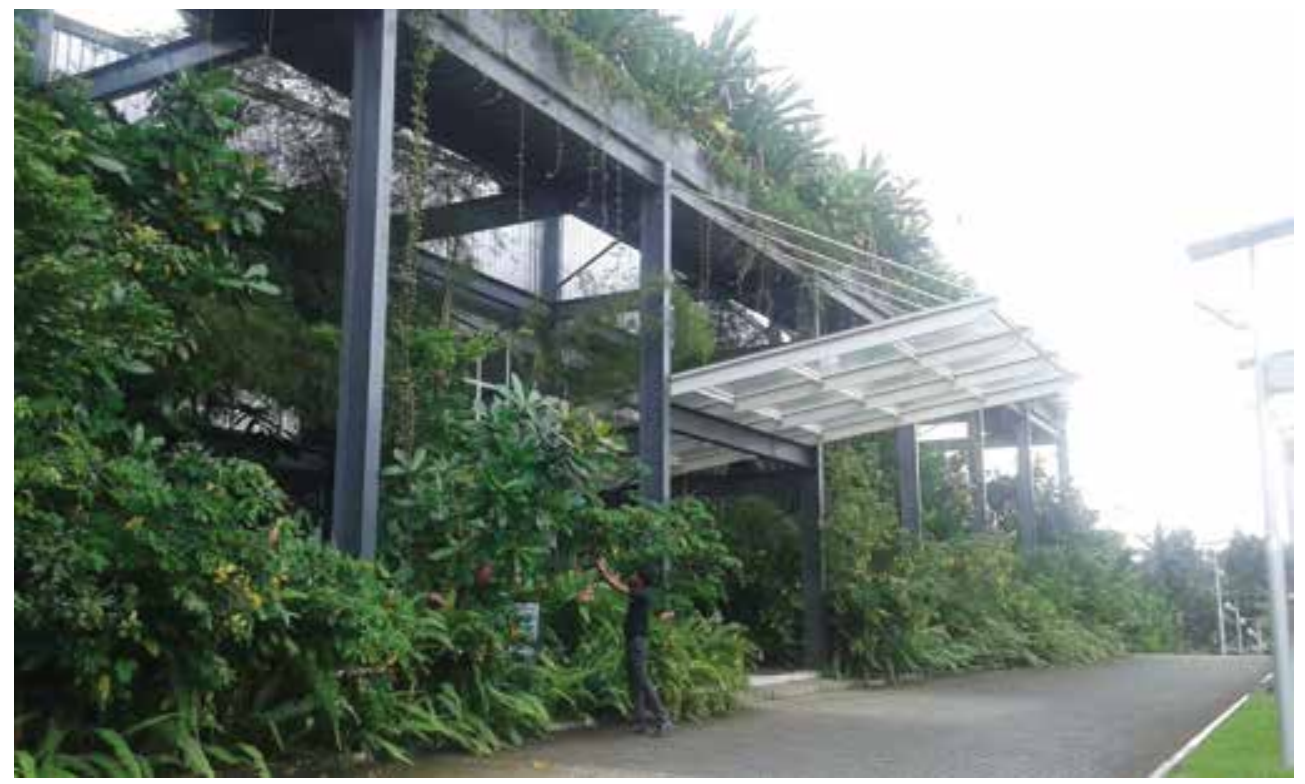

One of the factories, belonging to a large apparel maker in Sri Lanka, has become a carbon neutral factory mainly through a) being carbon efficient after making a Green House Gas (GHG) emission assessment and b) buying the carbon offsets from the world market in order to compensate for the remaining excess carbons. The apparel maker is using this facility to demonstrate its commitment to environmental preservation while achieving eco-efficiency.

\section{Life Cycle Accounting}

The authors noted the application of life cycle accounting considerations in the spheres of energy and water consumption, and material usage particularly in the design stage of buildings and plants among the Sri Lankan organizations. Some of the Sri Lankan enterprises under observation have attempted to optimize the use of sunlight, minimize the consumption of electricity, use environmentally friendly air-conditioning systems such as evaporator cooling systems, minimize the damage to trees and the environment (see Figure 5), and install water and waste management systems from the design stage itself. However, these Sri Lankan enterprises do not use life cycle environmental impact assessment ${ }^{6}$, as suggested by Bennett and James (1997). Though many companies identify the environmental impact of the organization's activities at the design or implementation stages, a systematic identification of them across the value chain and throughout the organizational operations was not observed.

$\overline{6}$ Life cycle environmental impact assessment is a holistic approach to identifying the environmental consequences of a product or service through its entire lifecycle and identifying opportunities for achieving environmental improvements (Bennett \& James, 1997). 


\section{NSBM Journal of Management}

Vol. 2, No. 1, January - June, 2016

\section{Figure 5: Environmentally Friendly Design of a Hotel}

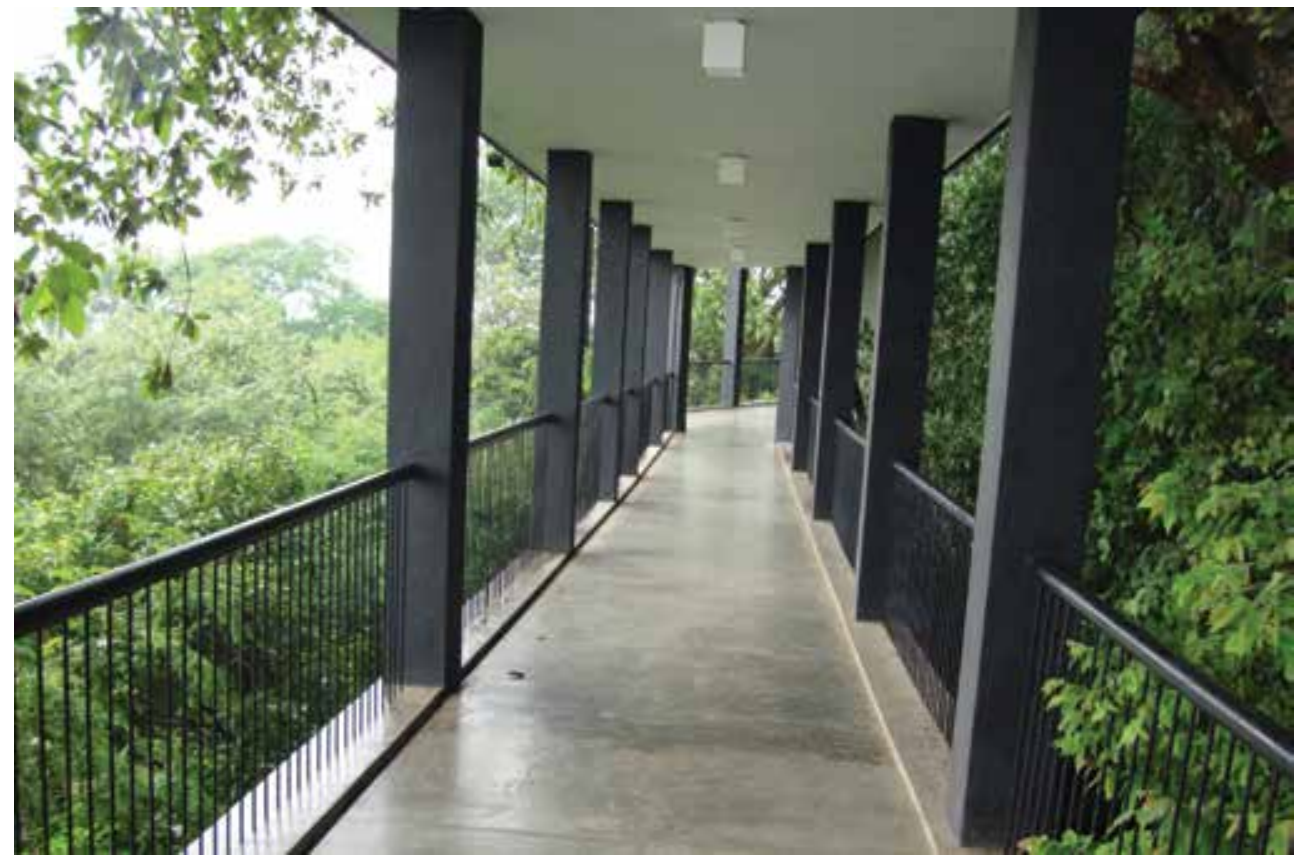

A famous green hotel in the country has built its entire structure upon columns enabling the rain water to flow freely from the mountainside into the nearby lake. Furthermore, this eco-friendly design facilitates the free movement of animals underneath the hotel. This demonstrates the application of environmental factors at the design stage of the hotel building.

\section{Accounting for Bio-diversity}

The authors observed certain other EMA applications such as biodiversity accounting particularly in the plantation sector. Accounting for bio-diversity (Jones 1996, 2003) is an emerging EMA practice among organizations which largely depend on the natural environment for their day-to-day operations. In the plantations sector, bio-diversity accounting is practised mainly owing to the need to follow accreditation standards such as the Rainforest Alliance and Ethical Tea Partnership (see Figure 6). The plantation companies, particularly the tea producing companies, are compelled to observe these standards due to the high price paid by the international buyers if tea comes from estates that are duly accredited. 
Environmental Management Accounting Practices and their Diffusion: The Sri Lankan Experience

Figure 6: Bio-diversity Conservation Efforts in the Plantation Sector

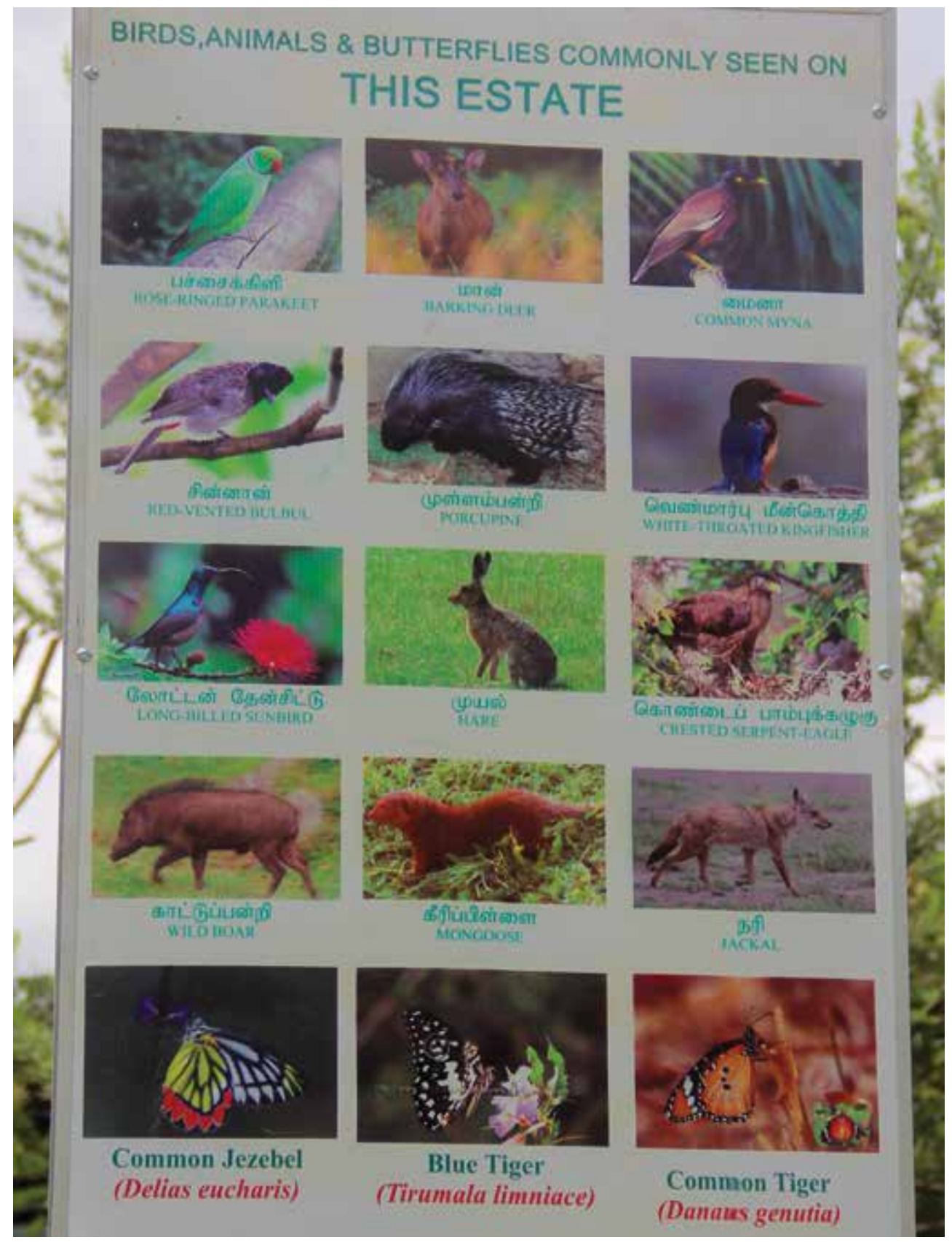

A Rainforest Alliance certified plantation company records and maintains details on flora and fauna found in its estates. Known as the 'bio-diversity log book' maintained for this certification it provides mainly physical EMA information to carry out accounting and management for biodiversity. 


\section{NSBM Journal of Management}

Vol. 2, No. 1, January - June, 2016

The practices described above are becoming popular and common among the Sri Lankan enterprises. Though not at the same level of application, Sri Lankan organizations adopt them with a view to deriving compliance efficiency and eco-efficiency and strengthening the strategic positioning, which are the three broad benefits as suggested by IFAC, (2005), Doody (2010), Williamson et al. (2006) and Windolph et al. (2014).

The next section presents how and why these EMA practices have diffused in Sri Lanka.

\section{Diffusion of EMA Practices in Sri Lanka}

According to Bjørnenak (1997) and Malmi (1999), diffusion of managerial technologies (in this case EMA) could take place from demand-pull and supply-push perspectives. The demand-pull perspective of diffusion can be discussed in the light of the information value of the accounting technologies (Bjørnenak 1997). However, the adoption of managerial technologies could also take place due to the active and purposeful role played by the propagators in the diffusion process (Abrahamson 1996, Bjørnenak 1997). Hence, this paper first focuses on the EMA adopters to demonstrate the demand-pull diffusion and then shed some light on the role of the propagators such as education providers and PABs in the supplypush diffusion of EMA.

\section{Diffusion of EMA among the Sri Lankan Enterprises}

With years of industry engagement in the field of sustainability, the authors witnessed a rapid diffusion of EMA among Sri Lankan enterprises in many different industry sectors referred to in the previous section (refer Gunarathne et al. 2015 for more details on EMA in Sri Lankan enterprises). This has been evident through various indicators such as the growing number of companies that have become carbon certified (or neutral), increasing participation in green competitions such as the Presidential Green Awards, Cleaner Production Awards of the National Cleaner Production Centre (NCPC), increasing number of companies that apply for sustainability reporting awards, and day-to-day press releases on green practices. Echoing a similar trend, the fast diffusion of EMA practices has been identified elsewhere in the world (Bartolomeo et al. 2000, Kokubu \& Kurasaka 2002, Jalaludin et al. 2011). While EMA is diffusing fast in Sri Lanka, its rapid adoption is clearly notable in some industries such as tourism, apparel, and banking and finance. This fast diffusion of EMA can be attributed to different reasons which are interrelated; they include environmental regulations, pressures stemming from different stakeholders, adoption of reporting standards such as Global Reporting Initiative (GRI), propagation of environmental management practices by various 
parties, and motivation to achieve internal efficiency.These reasons have been previously suggested by Doody (2010), Medley (1997), and Windolph et al. (2014), among many others. It therefore demonstrates that the drivers of environmental management and accounting in Sri Lanka are similar to what have prevailed elsewhere in the world.

However, the authors do not suggest here that EMA adoption has been smooth in Sri Lanka. Though the Sri Lankan organizations seem to adopt many EMA practices, they are often confined to a few isolated practices rather than a systematic and comprehensive approach as witnessed by Bartolomeo et al. (2000) in Europe and Lee (2011) in Korea. These practices have been implemented in a fragmentary manner as a response to various reasons mentioned previously, without an integrated system to reap the full benefits that EMA could offer. Hence, there is room for Sri Lankan organizations to become more comprehensive and systematic in EMA adoption to support the achievement of competitive advantage, management of risk and efficient utilization of resources. This requires top management commitment, support of various stakeholders across the value chain and improved awareness of EMA techniques (Gunarathne 2015).

\section{Role of the Propagators in EMA Diffusion in Sri Lanka}

Although there are many propagators in the diffusion process of EMA in Sri Lanka, this paper focuses only on the post-secondary education sector, which can make a significant impact on the prevalent accounting practices in Sri Lanka. Another reason is that new accounting practices such as EMA are first included in the curricula of universities and PABs before they are introduced to secondary level education.

\section{Role of the Universities}

Various facets of environmental management and its associated concepts have been traditionally covered in the curricula of the physical sciences, engineering and agriculture science undergraduate and master's level degree programmes in Sri Lanka. But these programmes have scarcely covered EMA as a core subject. In addition to these study programmes, the authors noted that some national universities have taken innovative measures to popularize EMA or environmental management in general. A case in point is the Department of Accounting of the University of Sri Jayewardenepura (USJ), which incorporated EMA in its degree programme a few years ago. It has introduced sustainability reporting, sustainability management accounting and integrated reporting at different levels of its degree programme with a view to grooming future sustainable leaders in the field of accounting. With the expectation of instilling transdisciplinary thinking and praxis in the 


\section{NSBM Journal of Management}

Vol. 2, No. 1, January - June, 2016

minds of future accountants as advocated by Tingey-Holyoak and Burritt (2012), some of these course units have adopted a pragmatic approach with field visits, workshops, industrybased learning methods, etc. (see Figure 7) (Gunarathne \& Alahakoon, forthcoming).

In addition, various academic departments have taken many innovative steps to popularize environmental management in Sri Lanka. For instance, the Department of Forestry and Environmental Sciences of the USJ has set up a Sustainability Centre and also conducts an annual research symposium on forestry and environment. Also, the Staff Development Centre of the University of Kelaniya and Department of Accounting of the USJ recently held conferences on green practices/sustainability management. Moreover, at university level, many Sri Lankan universities have shown an interest in promoting the 'green university' concept. For example, with the assistance of the United Nations Environmental Programme (UNEP) and United Nations Institute for Training and Research (UNITAR), two projects at the Universities of Sri Jayewardenepura and of Sabaragamuwa are underway to promote capacity building in Sustainable Consumption and Production (SCP). The ultimate objective of these projects is to inculcate environmentally-friendly attitudes, values and ethics in addition to promoting environmental awareness among the students (UNITAR 2016).

\section{Figure 7: A Field Visit Made by Accounting Undergraduates}

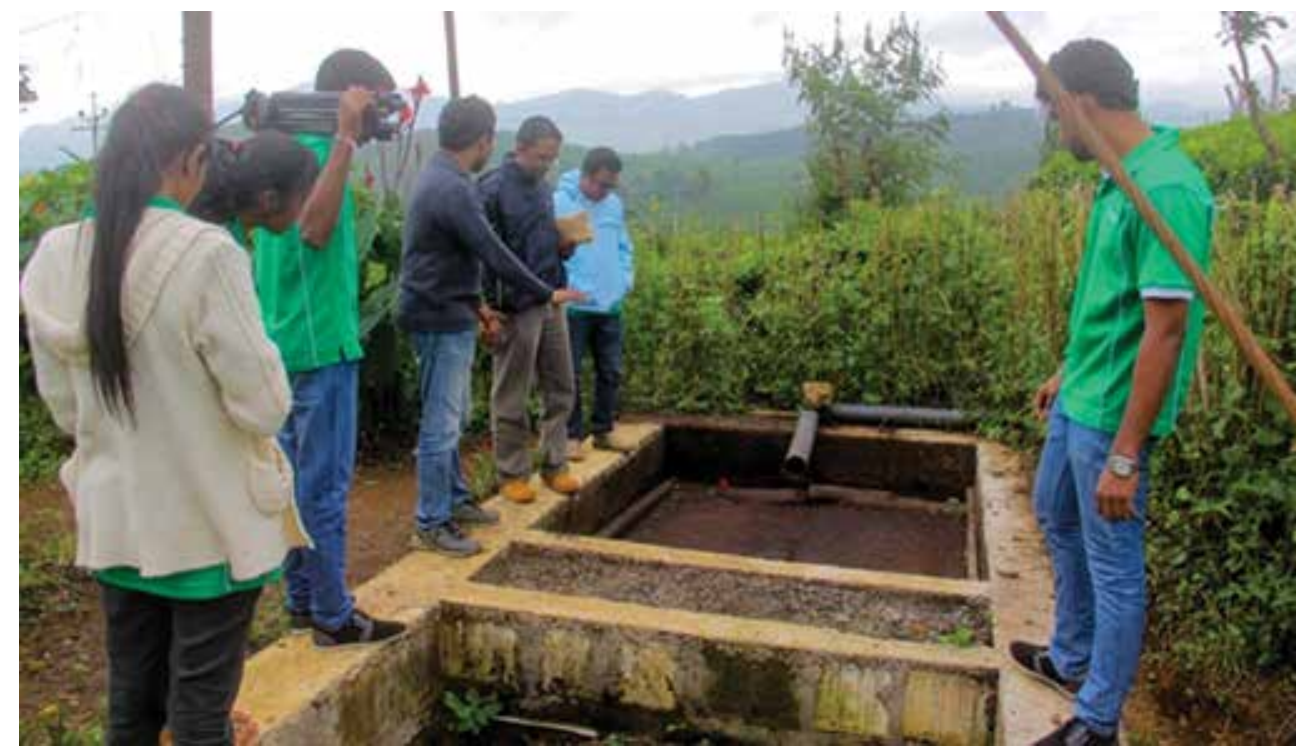

The students of the Department of Accounting, University of Sri Jayewardenepura, during a field visit to study the applicability of the concepts they learn in a course unit on Sustainability Management Accounting. This was a field visit to a plantation company to observe its environmental practices and impact of certification/accreditation standards such as the Rainforest Alliance on accounting practices. 
It should also be noted that a semi-government degree awarding institution the National School of Business Management (NSBM), has shown keen interest in this regard by promoting itself as a green university (NSBM 2015). Its Green University Town is a state-of-the-art university set amidst the lush greenery of the countryside and showcases environmental management practices in its design, operations and study programmes (see Figure 8).

\section{Figure 8: The Green University Town of NSBM}

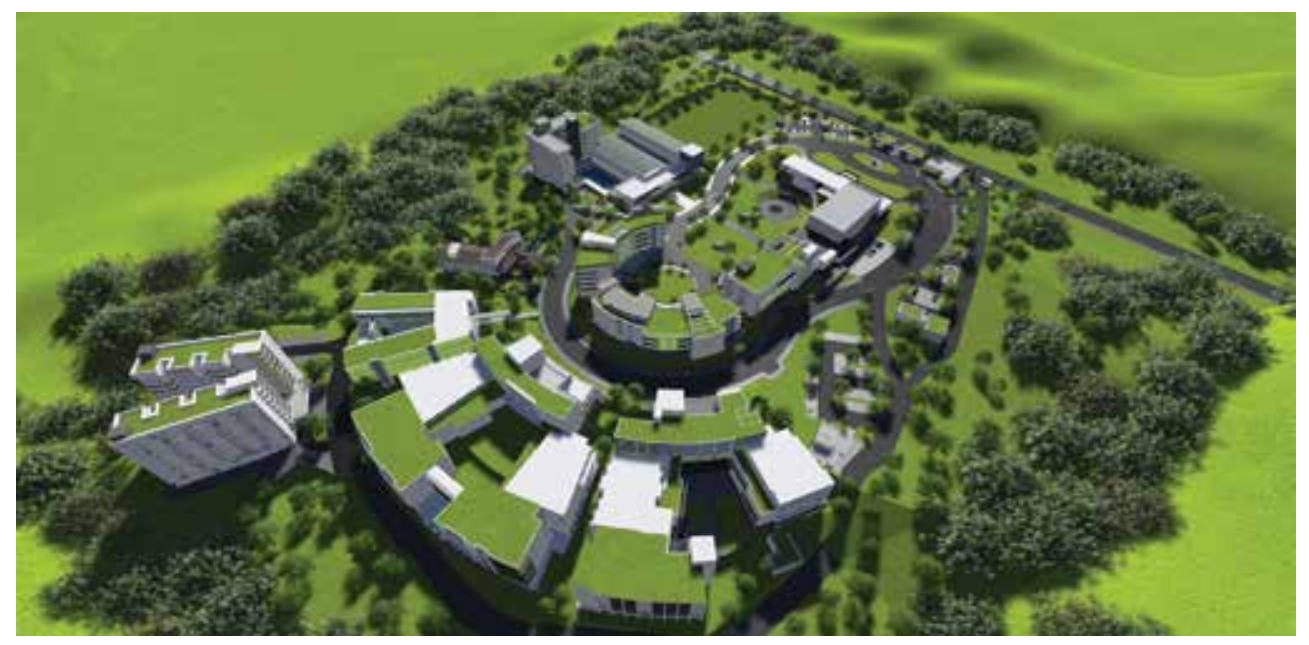

The Green University Town of NSBM is the first ever project of its nature in the whole of South Asia, with eco-friendly energy, water and waste management systems in its 26-acre land in Pitipana, Homagama.

\section{Role of PABs and their Membership}

As explained previously, the role played by PABs as propagators of EMA is worth looking at in order to get a holistic picture of the diffusion of the EMA practice in Sri Lanka.

An important feature with respect to environmental accounting education in Sri Lanka is the enthusiasm of the PABs to promote environmental accounting. In this respect they have taken several initiatives to popularize EMA (or sustainability accounting) such as organizing seminars, workshops and conferences on EMA and incorporating these aspects in their curricula. The four IFAC full member bodies ${ }^{7}$ have introduced environmental accounting

\footnotetext{
7 Currently in Sri Lanka there are five PABs, viz, Institute of Chartered Accountants of Sri Lanka (CASL), Institute of Certified Management Accountants of Sri Lanka (CMA), Association of Accounting Technicians of Sri Lanka (AAT), Chartered Institute of Management Accountants (CIMA) and Association of Chartered Certified Accountant (ACCA). CASL, CMA and AAT are indigenous bodies while CIMA and ACCA are of UK origin. Except AAT all other PABs are IFAC full member bodies (World Bank, 2015).
} 


\section{NSBM Journal of Management}

Vol. 2, No. 1, January - June, 2016

into their mainstream subjects at different levels. In addition, they host various sustainability reporting/integrated reporting award schemes in a bid to promote these practices. Moreover, all the PABs operating in Sri Lanka now prepare integrated annual reports ${ }^{8}$ themselves to provide guidance, motivation and models for companies to prepare their own integrated reports (Gunarathne \& Senarathne, forthcoming).

It is also imperative to look at the role of the members of these PABs (i.e., accountants), who eventually apply EMA in various Sri Lankan enterprises. An important characteristic of the EMA practice in Sri Lanka, as noted by the authors, is its development by professional groups other than accountants. Some of the EMA practices adopted such as accounting for energy and materials, waste accounting, and quantification of certain environmental costs are carried out by the engineers in many organizations. This resembles the early days of cost accounting such as introducing standard costing systems which were mainly shaped by engineers (Mattessich 2003, Kranowski 1977). The role of the accountant in some organizations was, therefore, marginal in the sphere of EMA. This trend has been prevalent mainly in the developed countries (Hopwood et al. 2005, Johnson 2002, Schaltegger \& Zvezdov 2015). The authors noted that even in the Sri Lankan context, accountants who should really play a key role in facilitating the enterprise's sustainable performance have only been on the sidelines of the operational process and have often allegedly performed only a gatekeeper role as noted by Schaltegger and Zvezdov (2015) in UK and Germany. Sri Lankan accountants will have to play a key role as suggested by Medley (1997) in achieving corporate sustainability. According to IFAC (2005), accountants have a special role in EMA since they have access to the important monetary data and information systems needed for EMA activities, the ability to improve or verify the quality of such information and the skills to use such information for decision making. The only way for the accounting profession to survive and to respond to the exigencies of sustainability is to make major revisions in accounting education (Gray \& Collison 2002).

It is the authors' view that despite the previously mentioned active role played by the PABs and the universities, the limited role played by Sri Lankan accountants in practice can be attributed to two main reasons. One is associated with the accounting education system in Sri Lanka, where EMA has only been recently introduced to the curricula of the universities and the PABs. Hence, when most of the accountants were not exposed to EMA during their student lives it will take time for them to adopt these practices in their workplace. Moreover, environmental education requires a trans-disciplinary approach (Tingey-Holyoak \& Burritt

\footnotetext{
$\overline{8}$ Integrated reports by focusing on five different levels of capitals, incorporates environment as another type of capital in the value creation of an organization (IIRC, 2013).
} 
2012) and the present accounting education system in the country still does advocate such an approach (Gunarathne \& Alahakoon, forthcoming). The other reason that hinders active involvement of Sri Lankan accountants in EMA practice is the level of support they receive from the workplace. Poor coordination between accounting and other functional departments, inadequate information capturing systems, lack of awareness of the importance of the environment, and preoccupation with existing work are some of the contributory factors in this regard. Poor coordination between accounting and other functional departments can be attributed to the excessive disciplinary approach to education that results in functional silos. However, it is noted that with the sustainability teams of different functional backgrounds such as engineering, marketing and production getting together with finance professionals, the journey of EMA has become quite adventurous, as suggested by Bartolomeo et al. (2000). This is evident in some companies as they calculate some advanced EMA measures such as a sustainability index that captures the performance of several environmental domains as a single coherent measure.

For instance, a large apparel maker has several Key Performance Indicators (KPIs) for its four material environmental domains, viz. waste, water, energy and carbon footprint (CFP). Each of these aspects has its own KPIs and weightings. The organization calculates a sustainability index by incorporating these four areas through a weighting system to arrive at a single value as follows:

Sustainability index $=\frac{(\text { water sub }- \text { index }+ \text { energy sub }- \text { index }+ \text { waste sub index }+ \text { CFP sub }- \text { index })}{4}$

Year 2013 is considered as the base year for the index and since then, the organization has calculated the index on a monthly basis. It is used to provide a single figure that indicates how the company has performed in terms of resource efficiency and management by highlighting the trend compared with the base year. The results of the sustainability index as well as individual KPIs are brought up at monthly operation reviews if there are any deviations to be addressed. The KPI results also provide feedback for resource allocation and signal the budgetary allocation requirements for the next period. This is an exercise carried out by the finance team with the help and inputs from the sustainability team who come from marketing, production, engineering and maintenance departments. In recognition of these notable practices, the apparel maker has been awarded many local and international green awards and sustainability reporting awards recently. This exemplifies how accountants with the help of other professionals bring in significant value additions for environmental management strategies of an organization. 
NSBM Journal of Management

Vol. 2, No. 1, January - June, 2016

\section{Conclusions}

The paper presents an overview of Sri Lankan EMA practices and its diffusion based on the authors' experiences. Though it is not a comprehensive coverage of all the aspects, the authors attempted to cover salient aspects such as common EMA tools and techniques, the drivers of EMA adoption and diffusion aspects including the role of the higher education and PABs in disseminating and promoting EMA. With the current level of interest and of diffusion, the authors anticipate a further increase in the adoption of environmental and EMA practices. Owing to the adoption of these novel managerial technologies, the accounting profession of the country is playing a leading role in the SAARC region, which has been acknowledged even by the World Bank (World Bank 2015). However, the authors are still not convinced that Sri Lanka, as a country, will fully benefit from these initiatives owing to various constraints, some of which have been discussed in the paper.

\section{Future areas for study}

The authors are of the view that there should be systematic studies in the future on the adoption of EMA or sustainability accounting from a diffusion point of view, which can offer many learning points for other countries. Though the authors did not analyze it deeply, the influence of the national culture on the adoption of EMA can also be an interesting area for study. Moreover, while dealing with Sri Lankan organizations, the authors noted that these organizations are at different levels of adoption of environmental strategies and hence EMA. Some organizations have developed their environmental management systems to a high level while other organizations are still at the infancy stage of adoption. Understanding how the level of maturity/development of EMA alongside environmental management also offers potential for future research. Hence, the areas for study are widely open and largely unexplored, and the authors consider this as an area with great potential for researchers.

\section{References}

Abrahamson, E 1996, 'Management fashion', Academy of Management Review, vol. 21, no. 1, pp. 254-285.

Bartolomeo, M, Bennett, M, Bouma, J, Heydkamp, P, James, P \&Wolters, T 2000, 'Environmental management accounting in Europe: current practice and future potential', The European Accounting Review, vol. 9, no. 1, pp. 31-52.

Bennett, M \& James, P 1997, 'Environment related management accounting: current practice and future trends', Greener Management International, vol. 17, pp. 33-51. 
Bennett, MJ, Bouma, J \& Walters, T 2002, Environmental Management Accounting: Informational and Institutional Developments, (eds.), Kluwer, Dordrecht.

Benson, C \& Clay EJ 2004, Understanding the Economic and Financial Impacts of Natural Disasters, The International Bank for Reconstruction and Development / The World Bank, Washington DC.

Bjørnenak, T 1997, 'Diffusion and accounting: the case of ABC in Norway', Management Accounting Research, vol. 8, no. 1, pp. 3-17.

Burritt, RL 2004, 'Environmental management accounting: roadblocks on the way to the green and pleasant land', Business Strategy and the Environment, vol. 13, pp. 13-32.

Burritt, R, Hahn, T \& Schaltegger, S 2002, ‘Towards a comprehensive framework for environmental management accounting: links between business actors and environmental management accounting tools', Australian Accounting Review, vol. 12, no. 2, pp. 39-50.

Central Bank of Sri Lanka (CBSL) 2013, Annual Report 2013, CBSL, Colombo.

CIA2016, Environment - Current Issues, viewed 23 July 2016, https://www.cia.gov/library/publications/ the-world-factbook/fields/2032.html

Chartered Institute of Management Accountants (CIMA) 2009, Survey on management accounting tools, CIMA, UK.

Conservation International (CI) 2005, Biodiversity Hotspots, CI, Washington.

Delmas, M \& Toffel, MW 2004, 'Stakeholders and environmental management practices: An institutional framework', Business Strategy and the Environment, vol. 13, pp. 209-222.

De Silva, KM 2014, A history of Sri Lanka, VijithaYapa, Colombo, Sri Lanka.

Doody, H 2010, Environmental sustainability: tools and techniques, The Society of Management Accountants of Canada, The American Institute of Certified Public Accountants and the Chartered Institute of Management Accountants.

Environmental Protection Agency (EPA) 1995, An introduction to environmental accounting as a business management tool: key concepts and terms, EPA, Washington, DC.

Fobes 2011, Financial effects of natural disasters, viewed 05 August 2016, http://www.forbes.com/ sites/greatspeculations/2011/03/15/financial-effects-of-natural-disasters/\#67610bae5ca8.

Greenhouse Gas Protocol (GHG) 2004, A corporate accounting and reporting standard, revised edition, World Business Council for Sustainable Development and World Resources Institute, ConchesGeneva/Washington.

Gray, SJ \& Vint, HM 1995, 'The impact of culture on accounting disclosures: some international evidence', Asia-Pacific Journal of Accounting, vol. 2, no. 1, pp.33-43.

Gunarathne, N 2015, 'Fostering the adoption of environmental management with the help of accounting: An integrated framework', in Rahim, MM \& Idowu, S, (eds.), Social Audit Regulation, Springer, Cham (ZG), pp. 301-324. 


\section{NSBM Journal of Management}

Vol. 2, No. 1, January - June, 2016

Gunarathne N \& Alahakoon Y forthcoming, 'Integrating futures thinking through transdisciplinarity into sustainability accounting education: Perspectives from an emerging South Asian economy' in Corcoran, PB, Weakland, J \& Wals, AEJ, (eds.), Envisioning Futures for Environmental and Sustainability Education, Wageningen Academic Publishers, Wageningen,Netherlands.

Gunarathne, N \& Lee, KH 2015, 'Environmental management accounting (EMA) for environmental management and organizational change', Journal of Accounting \& Organizational Change, vol. 11, no. 3, pp. $362-383$.

Gunarathne, N, Peiris, S, Edirisooriya, K \& Jayasinghe, R 2015, Environmental management accounting in Sri Lankan enterprises, Department of Accounting, University of Sri Jayewardenepura, Sri Lanka.

Gunarathne, N, Ranasinghe, AB \& Peiris, S 2014, Guidelines on environmental management accounting for Sri Lankan Enterprises, CMA, Colombo.

Gunarathne, N \& Senaratne, S forthcoming, 'Country readiness in adopting Integrated Reporting: A Diamond Theory approach from an Asian Pacific economy, in Lee, K \& Schaltegger, S, (eds.), Sustainability Accounting in the Asia Pacific Region, Springer, Netherlands.

Herzig, C, Viere, T, Schaltegger, S \& Burritt, RL 2012, Environmental management accounting: case studies of South-East Asian Companies, Routledge, London.

Hopwood, B, Mellor, M \& O’Brien, G 2005, 'Sustainable development: mapping different approaches', Sustainable Development, vol. 13, pp. 38-52.

IIRC 2013, The International $<I R>$ Framework, viewed 12 July 2016, http://integratedreporting.org/ wp-content/uploads/2013/12/13-12-08-THE-INTERNATIONAL-IR-FRAMEWORK-2-1.pdf.

International Federation of Accountants (IFAC) 2005, International guidance document: environmental management accounting, IFAC, New York.

Jalaludin, D, Sulaiman, M \& Ahmad, NNN 2011, 'Understanding environmental management accounting (EMA) adoption: a new institutional sociology perspective', Social Responsibility Journal, vol. 7 , no. 4 , pp. 540-557.

Johnson, HT 2002, 'A former management accountant reflects on his journey through the world of cost management', Accounting History, vol. 7, no. 9, pp. 9-21.

Jones, MJ 1996, 'Accounting for biodiversity: a pilot study', The British Accounting Review, vol. 28, no. 4, pp. 281-303.

Jones, MJ 2003, 'Accounting for biodiversity: operationalizing environmental accounting', Accounting, Auditing \& Accountability Journal, vol. 16, no. 5, pp. 762-789.

Kokubu, K \& Kurasaka, T 2002, 'Corporate environmental accounting: a Japanese perspective', in Bennett, M, Bouma, JJ \&Wolters, T (eds.), Environmental Management Accounting: Informational and Institutional Developments, Kluwer, Dordrecht, pp. 161-173.

Kranowski, N 1977, 'The historical development of standard costing systems until 1920'.Journal of Accountancy, vol. 144, no. 6, pp. 66-73.

Lee, KH 2009, 'Why and how to adopt green management into business organizations?: The case study of Korean SMEs in manufacturing industry', Management Decision, vol.47 no.7, pp.1101-1121. 
Lee, KH 2011, 'Motivations, barriers, and incentives for adopting environmental management (cost) accounting and related guidelines: a study of the Republic of Korea', Corporate Social Responsibility and Environmental Management, vol. 18, pp. 39-49.

Malmi, T 1999, 'Activity-based costing diffusion across organizations: an exploratory empirical analysis of Finnish firms', Accounting, Organizations and Society, vol. 24, pp. 649-72.

Mattessich, R 2003, 'Accounting research and researchers of the nineteenth century and the beginning of the twentieth century: an international survey of authors, ideas and publications', Accounting, Business and Financial History, vol. 13, no. 2, pp. 125-170.

Medley, P 1997, 'Environmental accounting - what does it mean to professional accountants?', Accounting, Auditing \& Accountability Journal, vol. 10, no. 4, pp. 594-600.

Meyer, G 2004, 'Diffusion Methodology: Time to Innovate?', Journal of Health Communication: International Perspectives, vol. 9, pp. 59-69.

Ministry of Environment and Renewable Energy 2011, Technology needs assessment and technology action plans for climate change mitigation, Ministry of Environment and Renewable Energy, Sri Lanka.

NSBM Quarterly News Letter 2015, NSBM green university town a moving story, vol. 1, no. 1 25th February, 2015.

Salzmann, O, Ionescu-Somers, A \& Steger, U 2005, 'The business case for corporate sustainability: literature review and options', European Management Journal, vol. 23, no. 1, pp. 27-36.

Schaltegger, S, Gibassier, D \& Zvezdov, D 2013, 'Is environmental management accounting a discipline? A bibliometric literature review', Meditari Accountancy Research, vol. 21, no. 1, pp. 4-31.

Schaltegger, S \& Zvezdov, D 2015, 'Gatekeepers of sustainability information: exploring the roles of accountants', Journal of Accounting and Organizational Change, vol. 11, no. 3, pp. 333 - 361.

Soonawalla, K 2006, 'Environmental management accounting', in Bihami, A (ed.), Contemporary Issues in Management Accounting, Oxford University Press, New York, NY, pp. 380-406.

South Asia Co-operative Environment Programme (SACEP) 2014, Post 2015 South Asia Development Agenda, SACEP, Colombo.

Sroufe, R, Montabon, F, Narasimhan, R \& Wang, X 2002, 'Environmental management practices: a framework', Greener Management International, vol. 40, pp. 23-44.

Strobe, M \& Redmann, C 2002, 'Flow cost accounting, an accounting approach based on the actual flows of materials', in Bennett, M, Bouma, JJ \& Walters, T, (eds.), Environmental Management Accounting: Informational and Institutional Developments, Kluwer, Dordrecht, pp. 67-82.

Tingey-Holyoak, L \& Burritt, R 2012, ‘The trans-disciplinary nature of accounting: a pathway towards the sustainable future of the profession', in Evans, E, Burritt, R \& Guthrie, J, (eds.), Emerging Pathways for the Next Generation of Accountants, The Institute of Chartered Accountants in Australia, Australia, pp. 93-103.

UNITAR (2016), Sri Lankan universities go green, viewed 27 July 2016, https://www.unitar.org/srilankan-universities-go-green-one-day-trainings-sustainable-consumption-and-production. 


\section{NSBM Journal of Management}

Vol. 2, No. 1, January - June, 2016

United Nations 2016, Sustainable development goals (SDGs), viewed 20 July 2016, available online http://www.undp.org/content/undp/en/home/sdgoverview/post-2015-development-agenda.html.

United Nations Environment Programme and Development Alternatives 2008, South Asia environment outlook 2009: United Nations Environment Programme (UNEP), Bangkok, South Asian Association for Regional Cooperation (SAARC),Kathamndu and Development Alternatives (DA), New Delhi.

United Nations Environment Program (UNEP) \& United Nations Industrial Development Organization (UNIDO) 1991, Audit and reduction manual for industrial emissions and waste, UNEP and UNIDO, Paris.

Williamson, D, Lynch-Wood, G \& Ramsay, J 2006, 'Drivers of environmental behavior in manufacturing SMEs and the Implications for CSR', Journal of Business Ethics, vol. 67, no. 3, pp. 317-330.

Wilmshurst, TD \& Frost, GR 2001, 'The role of accounting and the accountant in the environmental management system', Business Strategy and the Environment, vol. 10, pp. 135-147.

Windolph, SE, Harms, D \& Schaltegger, S 2014, 'Motivations for corporate sustainability management: contrasting survey results and implementation', Corporate Social Responsibility and Environmental Management, vol. 21, pp. 272-285.

World Bank 2015, Report on the observance of standards and codes, Accounting and Auditing- Sri Lanka, World Bank, Washington. 